\title{
Knowledge of Human Papilloma Virus (HPV) and its Vaccine among Female Undergraduates in Awka, South Eastern Nigeria
}

\author{
Ezebialu Chinenye Uzoamaka ${ }^{1}$, Ezebialu Ifeanyichukwu Uzoma², Ezeifeka George Okey ${ }^{3}$, Nwobu Reuben Udeozo \\ Anyichukwu ${ }^{4}$, Unegbu Valentine Nnachetam ${ }^{5}$, Eze Ebere Mary ${ }^{6}$, Ezenyeaku Cyril Chukwuma ${ }^{2}$
}

\section{Ezebialu Chinenye Uzoa- maka', Ezebialu Ifeanyichukwu $\mathrm{U}^{2 *}$, Ezeifeka George $\mathrm{O}^{3}$, Nwobu Reuben Udeozo A4, Unegbu Valentine $\mathrm{N}^{5}$, Eze Ebere $\mathrm{M}^{6}$, Ezenyeaku Cyril $C^{2}$}

'Department of Microbiology, Godfrey Okoye University, Thinker's corner, Emene, Enugu, NIGERIA.

${ }^{2}$ Department of Obstetrics and Gynaecology, Chukwuemeka Odumegwu Ojukwu University, Awka, NIGERIA. ${ }^{3}$ Department of Veterinary Microbiology and Parasitology, College of Veterinary Medicine, Micheal Okpara University of Agriculture Umudike, Abia State, NIGERIA.

${ }^{4}$ Department of Microbiology, Paul University, Awka, NIGERIA.

${ }^{5}$ Department of Microbiology, Renaissance University, Enugu, NIGERIA. ${ }^{6}$ Department of Microbiology, Novena University, Delta State, NIGERIA.

\section{Correspondence}

Ezebialu Ifeanyichukwu Uzoma Department of Obstetrics and

Gynaecology, Chukwuemeka Odumegwu Ojukwu University, Awka Campus, NIGERIA.

Mobile no: +234 8034723600

Email: iu.ezebialu@coou.edu.ng

History

- Submission Date: 27-02-2018

- Revised Date: 30-03-2018

- Accepted Date: 08-05-2018

DOI : 10.5530/ijmedph.2018.2.14

Article Available online

http://www.ijmedph.org/v8/i2

\section{Copyright}

(C) 2018 Phcog.Net. This is an openaccess article distributed under the terms of the Creative Commons Attribution 4.0 International license.

\begin{abstract}
Background: Human Papillomavirus (HPV) is a known and well documented cause of cervical cancer. Primary prevention of HPV infection using vaccine is possible and some approved vaccines are already in use. Objective: The aim of this research was to ascertain the knowledge of HPV infection and HPV vaccines, among female students of Nnamdi Azikiwe University, Awka. Method: A cross sectional study of three hundred and sixty seven (367) female students selected randomly across 6 faculties of Nnamdi Azikiwe University, Awka using semi structured questionnaires. Information was obtained on their demographic characteristics, knowledge of HPV infection, mode of transmission, associated diseases and knowledge of HPV vaccine. Data was coded and analyzed using SPSS version 21. Results were presented as frequency tables. Association between variable was tested using the Chi square test and significant level was set at $p<0.05$. Results: One hundred and ten respondents $(30.0 \%)$ had knowledge of HPV infection, significantly more among students of biosciences. Of these, $64.5 \%(71 / 110)$ identified it as a sexually transmitted infection and associated it with cervical cancer. Only 15.8\% (58/367) had knowledge of Human Papilloma Virus vaccine. Respondents from the faculty of Biosciences had significantly superior knowledge and the most common sources of information were the internet and school lectures. Conclusion: This study has shown a poor knowledge of HPV and its vaccine among these undergraduates and so underscoring the need for scaling up awareness campaigns in our society. We recommend the introduction of important public health issues like cervical cancer in the general study syllabus for undergraduates.
\end{abstract}

Key words: Knowledge, Human Papillomavirus, Vaccine, Undergraduates, Nigeria.

\section{INTRODUCTION}

Human Papilloma Virus (HPV) is a sexually transmitted infection ${ }^{1,2}$ and is transmitted primarily through skin to skin contact. ${ }^{3} \mathrm{HPV}$ constitutes $51 \%$ of all Sexually Transmitted Infections and has been tagged as a marker of having had sex. ${ }^{4}$

Different strains of HPV exist and can be grouped into high risk and low risk strains. Human papilloma virus is known to be associated with certain diseases including ano-genital warts, cervical cancer, penile cancer, vulval cancer, anal cancer and laryngeal papillomatosis. However, due to its public health importance, cervical cancer has become more prominent and so has attracted more attention than others. Persistence of HPV infection is a well documented cause of cervical cancer. ${ }^{5-7}$ Human Papilloma Virus has also been isolated in $99.7 \%$ of cervical cancer worldwide, ${ }^{8} 97.9 \%$ in Portugal, ${ }^{9} 90.4 \%$ in Sub-Saharan Africa ${ }^{10}$ and $90.7 \%$ in Nigeria. ${ }^{11}$ Since the etiological role of Human Papilloma Virus in cervical cancer has been established, it is clear that preventing HPV infections will ultimately lead to a drastic reduction in the incidence of cervical cancer and other diseases associated with the virus. Scientific advances have

added HPV vaccines to the armamentarium for the prevention of HPV infection

Availability of vaccines against the high risk HPV serotypes provides a very good opportunity for primary prevention of cervical cancer. Availability of this scientific breakthrough will be effective only if it is matched with good knowledge among women. Despite the burden of cervical cancer in Nigeria, some authors have documented poor knowledge of HPV and its infection among Nigerian women. ${ }^{12-14}$ This study aims at assessing the knowledge of Human Papilloma Virus infection and its prevention among female university students in south eastern Nigeria. Based on the findings of this study, recommendations will be made to policy makers to enhance knowledge.

\section{MATERIALS AND METHODS}

This was a cross-sectional survey of three hundred and sixty seven (367) female students of Nnamdi Azikiwe University Awka from October 1 to November 30, 2015. Six faculties were randomly selected out of the 10 faculties in the university. From each of the selected faculties, three departments were selected 
randomly. The students in the selected departments were approached just before the commencement of a lecture. The nature of the study was explained to them to obtain their consent. A minimum sample size of 247 was calculated using $17.7 \%$ awareness documented in a similar study ${ }^{13}$ and giving provision for $20 \%$ attrition.

The study instrument was a semi structured self-administered questionnaire consisting of 25 question items. The questionnaire was previously pretested among female undergraduates of Chukwuemeka Odumegwu Ojukwu University but these were not included in the final analysis. The questionnaire was modified accordingly after the pretest. The participants were encouraged to fill the questionnaires independently and these were collected back by the researchers immediately. They were not allowed to take the questionnaires away so as to help maintain confidentiality. Ethical approval for the study was obtained from the ethics committee of Chukwuemeka Odumegwu Ojukwu University Teaching hospital Awka.

The questionnaire contained a total of twenty five questions that probed into their sociodemographic characteristics, awareness of HPV and its infection, knowledge of diseases associated with HPV infection and knowledge of its prevention. Data was coded and descriptive analysis was done using the Statistical Software for Social Sciences (IBM SPSS statistics version 21). The Chi square test was used to test for associations between variables and significant level was set at P-value $\leq 0.05$.

\section{RESULTS}

Of the 400 questionnaires distributed, 367 were correctly completed (91.8\% response) for response on awareness of HPV and its vaccine and these formed the basis for the analysis. The mean age of the respondents was $23.4 \pm 5.9$ years. The modal age group was $20-24$ years $(159,43.3 \%)$. Three hundred and eight were single, 57 were married while 2 were widowed. The socio-demographic characteristics of the participants are displayed in Table 1.

Out of the 367 respondents, 110 (30.0\%) had heard of Human Papilloma Virus. Knowledge level was determined by the proportion that answered 'yes' to awareness and mode of transmission. The age group that had highest knowledge of HPV infection was 25-29 (22/43, 51.2\%), while the least was 15-19(14/78, 17.9\%). The relationship between knowledge of $\mathrm{HPV}$ infection and age was statistically significant at $\mathrm{P}=0.018$. Although more married respondents knew about HPV, marital status did not significantly affect awareness of HPV $(\mathrm{p}=0.63)$. Respondents from the faculty of Biosciences had a significantly higher awareness level than those from other faculties $(p<0.001)$. Table 2 shows the relationship between awareness of HPV and certain respondents' charateristics.

Of those who were aware of HPV, 71(64.5\% or 19.3\% of all the respondents) identified HPV as a sexually transmitted infection. Eighty four respondents knew the existence of HPV serotypes. Seventy one respondents associated high risk HPV with cervical cancer while five respondents associated low risk HPV with cervical cancer.

One hundred and fourteen respondents correctly identified diseases associated with HPV infection to include: cervical cancer (62), anogenital warts (36), penile cancer (11) and vulval cancer (5).

Only $15.8 \%$ (58/367) of the respondents knew of the availability of HPV vaccines. Respondents from the faculty of biosciences and those who were young significantly had more knowledge of HPV vaccine (Table 2). Sources of information included internet $(28,46.7 \%)$, school $(11,13.3 \%)$, media $(4,6.7 \%)$, friends $(3,5.0 \%)$ and others $(6,1.6 \%)$.

\section{DISCUSSION}

This study has shown a poor knowledge of Human Papilloma Virus among these female undergraduates. The fact that only $30 \%$ of the

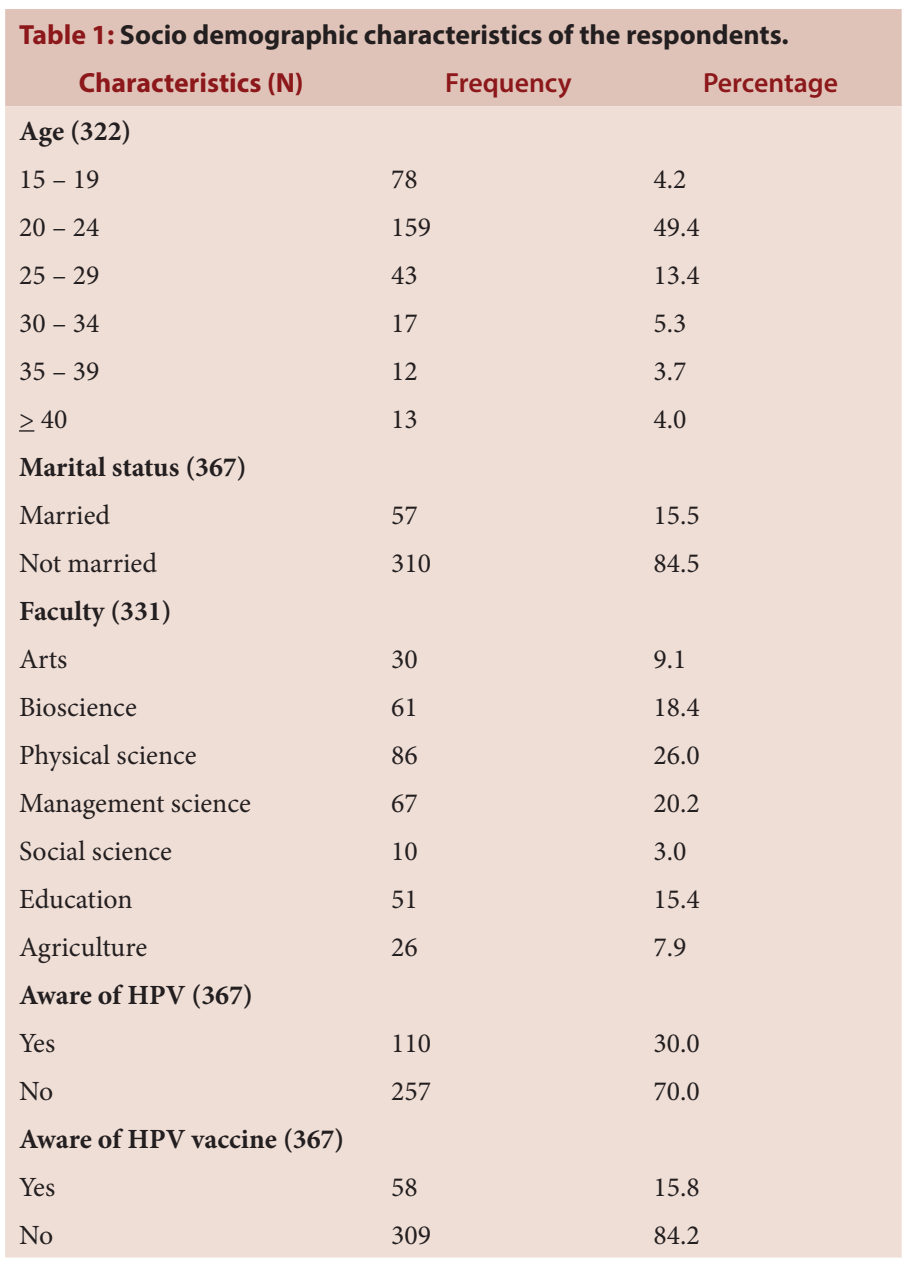

respondents were aware of this important virus underscores the enormity of the problem. This finding is similar to those from other parts of the country. The finding of $30 \%$ knowledge in the present study appears to be an improvement on that of $17.7 \%$ by $\mathrm{Makwe}^{13}$ among undergraduates in Lagos, Nigeria. This may be explained by the time effect as the present finding is coming about five years after the previous one. Several programmes on the prevention of cervical cancer have been organized over time and this would have increased the awareness of HPV among the populace. Similar situation has been observed in more developed nations. Before the introduction of vaccines, Di Giuseppe ${ }^{15}$ observed a poor knowledge of HPV (23.3\%) among adolescents but four years later a good knowledge (75.0\%) was documented by Sopracordevole ${ }^{16}$ among teenagers.

Another study done among antenatal women reported even a poorer knowledge. ${ }^{12}$ This is expected as antenatal women are a heterogeneous group of educated and non-educated women. The study population in this study was female undergraduates and so this explains why the sources of information were mainly related to educational materials. Level of awareness of HPV was significantly higher among respondents from the faculty of Biosciences. This is expected because HPV is covered by course curriculum of this faculty and so they are more likely to have good information about the virus. It is clear that wide variations may exist in the awareness of HPV among women in different populations. More developed nations expectedly will report relatively better awareness because of more organized awareness programs. A systematic review of 39 studies showed a very wide variation in the awareness level. ${ }^{17}$

A good proportion of those who were aware of HPV identified it as a sexually transmitted infection. This finding is important because it has 
Table 2: Association between awareness of HPV and its vaccine and selected sociodemographic characteristics of the respondents.

Variable

Awareness of HPV

Awareness of HPV vaccines

\begin{tabular}{|c|c|c|c|c|c|c|}
\hline & Yes & No & $\begin{array}{l}\text { chi sq p } \\
\text { value }\end{array}$ & yes & No & $\begin{array}{l}\text { chi sq p } \\
\text { value }\end{array}$ \\
\hline \multirow[t]{2}{*}{ Age: } & & & 15.33 & & & 19.65 \\
\hline & & & 0.018 & & & 0.07 \\
\hline $15-19$ & 14 & 64 & & 7 & 7 & \\
\hline $20-24$ & 50 & 109 & & 27 & 22 & \\
\hline $25-29$ & 22 & 21 & & 11 & 11 & \\
\hline $30-34$ & 5 & 12 & & 4 & 1 & \\
\hline $35-39$ & 4 & 8 & & 1 & 3 & \\
\hline 40 and above & 3 & 10 & & 1 & 1 & \\
\hline Marital status: & & & 0.080 .77 & & & 0.360 .55 \\
\hline Not married & 92 & 218 & & 50 & 41 & \\
\hline Married & 18 & 39 & & 8 & 9 & \\
\hline \multirow[t]{2}{*}{ Faculty: } & & & $33.47<$ & & & 34.14 \\
\hline & & & 0.001 & & & 0.002 \\
\hline Art & 13 & 27 & & 6 & 6 & \\
\hline Bioscience & 33 & 28 & & 15 & 17 & \\
\hline \multicolumn{7}{|l|}{ Physical } \\
\hline sciences & 14 & 72 & & 10 & 4 & \\
\hline Education & 17 & 34 & & 9 & 8 & \\
\hline Agriculture & 12 & 14 & & 6 & 6 & \\
\hline \multicolumn{7}{|l|}{ Management } \\
\hline sciences & 15 & 52 & & 8 & 7 & \\
\hline
\end{tabular}

a potential to influence campaign for the prevention of HPV infection. Apart from just being aware of HPV infection, basic knowledge of HPV infection was about average as $64.5 \%$ of those who were aware of HPV associated it with cervical cancer.

Clearly, HPV vaccine is a veritable tool in the primary prevention of HPV infections and cervical cancer. These respondents with fairly good knowledge of HPV, on the contrary, had a poor knowledge of HPV vaccine as only $15.8 \%$ of them knew of the existence of the vaccines. It is also important to note that younger females and those from the faculty of Bioscience had significantly better knowledge than others. This underscores the importance of educational activities in improving knowledge. The poor knowledge of HPV vaccines observed is very similar to $14.4 \%$ observed among undergraduates in western Nigeria. ${ }^{13}$ Among antenatal clients, Agida documented even a lower knowledge of $7.8 \% .^{12}$ The very poor knowledge among antenatal clients may be because these women are not exposed to educational materials on the issue as opposed to the respondents in the present study who were active students. Expectedly, vaccine use among these respondents was poor and many had no idea how to access it.

\section{CONCLUSION}

The study has shown a poor knowledge of Human Papilloma Virus and its vaccines among these respondents and this underscores the need for scaling up campaign on awareness of cervical cancer. Superior knowledge observed among participants from the faculty of Bioscience suggests that educational materials are important tools in improving health information. The authors recommend the introduction of important public health issues like cervical cancer into the general studies syllabus of undergraduates.

\section{CONFLICT OF INTEREST}

The authors declare no conflict of interest.

\section{ABBREVIATIONS}

HPV: Human Papilloma Virus.

\section{REFERENCES}

1. Centre for Disease Control and Prevention. Human Papillomavirus: HPV Information for Clinicians. 2007. Available at www.cdc.gov/std/hpv (Accessed December $17^{\text {th }}, 2017$ )

2. Sellors JW, Karwalajtys TL, Kaczorowski J, Mahony JB, Lytwyn A, Chong S, et al. Survey of HPV in Ontario Women Group. Incidence, clearance and predictors of human Papillomavirus infection in women. Canadian Medical Association Journal. 2003;168(4):421-5.

3. Elien BM. Human Papillomavirus and Cervical cancer. Clinical Microbiology Reviews. 2003;16(1):1-17.

4. Bonstra H. Comprehensive approach needed to combat sexually transmitted infections among youth. The Gutmarcher Report on Public Policy. 2004;7(1):3-4

5. Bosch FX, Burchell AN, Schiffman M, Guliano AR, De Sanjose S, Bruni L, et al. Epidemiology and natural history of Human Papillomavirus infections and type specific implication on cervical neoplasia. Vaccine. 2008;26(10):K1-K16.

6. Franco EL, Villa LL, Ruiz A, Costa MC. Transmission of cervical human papillomavirus infection by sexual activity: Differences between low and high oncogenic risk types. Journal of Infectious Diseases. 1995;172(3):756-63.

7. De Jong A, Van Poelgeest MI, Van der Hulst JM, Drijfhout JW, Fleuren GJ, Melief $\mathrm{CJ}$, et al. Human papillomavirus type 16-positive cervical cancer is associated with impaired CD4+ T-cell immunity against early antigens E2 and E6. Cancer Research. 2004;64(15):5449-55

8. Walboomers JM, Jacob MV, Manos ML, Bosch FX, Kummer JA, Shah KV, et al. Human Papillomavirus is a necessary cause of invasive cervical cancer worldwide. The Journal of Pathology. 1999;189(1):12-9.

9. Pista A, De Oliveira CF, Lopes C. Human Papillomavirus type distribution in Cervical Intraepithelial Neoplasia grade 2/3 and Cerical Cancer in Portugal: A Cleopatre 11 Study. International Journal of Gynaecological Cancer. 2013;23(3):500-6

10. Denny L, Adewole I, Anorlu R, Dreyer G, Moodley M, Smith T, et al. Human Papillomavirus prevalence and type distribution in invasive cervical cancer in Sub-Saharan Africa. International Journal of Cancer. 2014;134(6):1389-98

11. Okolo C, Franceschi S, Adewole I, Thomas JO, Follen M, Snijders PJ. Human papillomavirus infection in women with and without cervical cancer in Ibadan, Nigeria. Infect Agent Cancer. 2010;5(1):24

12. Agida TE, Akaba GO, Isah AY, Ekele B. Knowledge and perception of human papillomavirus vaccine among antenatal women in a Nigerian tertiary hospital. Nigerian Medical Journal. 2015;56(1):23-7.

13. Makwe CC, Anorlu RI, Odeyemi KA. Human papillomavirus HPV infection and vaccines: knowledge, attitude and perception among female students at the University of Lagos, Lagos, Nigeria. Journal of Epidemiology and Global Health. 2012;2( 4):199-206

14. Owonikoko KM, Afolabi AF, Adebusoye LA, Atanda OO. Human Papilloma Virus Vaccine: knowledge, attitude and perception of parents in Southwest, Nigeria. Medical Sciences and Public Health. 2013;1(1):13-9.

15. Di Giuseppe G, Abbate R, Luguori G, Albano L, Angelillo IF. Human Papillomavirus and vaccination: knowledge, attitudes, and behavioural intention in adolescents and young women in Italy. British Journal of Cancer. 2008;99(2):225-9.

16. Sopracordevole F, Cigolot F, Gardonio V, Di Giuseppe J, Boselli F, Ciavattini A. Teenagers' knowledge about HPV infection and HPV vaccination in the first year of the public vaccination programme. European Journal of Clinical Microbiology and Infectious Diseases. 2012;31(9):2319-25.

17. Klug SJ, Hukelmann M, Blettner M. Knowledge about infection with human papillomavirus: A systematic review. Prev Med. 2008;46(2):87-98. 